\title{
ABOUT LIFELONG AND REAL LIFELONG SENTENCE - (SEMI)PERMEABILITY OF THEORY AND PRACTICE - SUPRANATIONAL JUDICIAL APPROACH BY THE EUROPEAN COURT OF HUMAN RIGHTS
}

\author{
SOBRE A VIDA ÚTIL E A SENTENÇA REAL AO LONGO DOS TEMPOS - (SEMI) \\ PERMEABILIDADE DE TEORIA E PRÁTICA - ABORDAGEM JUDICIAL \\ SUPRANACIONAL DO TRIBUNAL EUROPEU DOS DIREITOS HUMANOS
}

\section{ACERCA DE LA FECHA DE VIDA LARGA Y REAL - (SEMI) LA PERMEABILIDAD DE LA TEORÍA Y LA PRÁCTICA - EL ENFOQUE JUDICIAL SUPRANACIONAL POR LA CORTE EUROPEA DE DERECHOS HUMANOS}

\author{
KATONA TIBOR \\ tdrkatona@gmail.com \\ University of Science in Szeged, Hungary.
}

\begin{abstract}
Annoying moreover disturbing situation has been formed around since the total abolition of death penalty in the countries forming High Contracting Parties of the European Convention on Human Rights (47 States). Different pros and cons has been raising ever since. Whether there might be a supplementary penalty for the most brutal, torturelike and cruel felonies having been committed mainly for innocent human beings depriving their life in aggravated forms? The answer is: 'yep'..... with a lot of barriers, preconditions and prerequisits. Thinking deeply about deprivation of liberty for the whole life of the defendant/convicted whether the State is empowered to do that? The judiciary of the European Court of Human Rights (in Strasbourg/France) itself could not answer consequently the eagerly rampant question: the Vinter Case and afterwards the Hutchinson case have formed controversial enforcement-compromising viewpoints. Hungary has introduced a very special legal remedy giving back the hope to be released - even conditionally: - after spending 40 years imprisonment a strictly formed National Commision is being entitled to revise the convicted person's behaviour and attitude demonstrated during the imprisonment and presuming whether he/she might be returned to the normal society..... heavy duty for the Commission and heavy precondition for the imprisoned person. The essay tries to clarify why it has been so hard to achieve a more or less compromise solution in order to comply with the Convention's spirit and written text. Enjoy and form You own opinion.
\end{abstract}

Keywords: European Commission on Human Rights; Death penalty; Abolition.

\section{RESUMO}

Desde a proposta de abolição da pena de morte nos países que formam as Altas Partes Contratantes da Convenção Europeia dos Direitos do Homem (47 Estados), gerou-se uma discussão preoccupante e perturbadora. Argumentos distintos, a favor e contra, tem aumentado desde então. Poderia haver uma penalidade suplementar aos crimes mais brutais, semelhantes a tortura e a tratamento desumano ou cruel, privando a vida de modo agravado? A resposta é: "sim" ... com muitas barreiras, pré-condições e pré-requisitos. Pensando profundamente na privação de liberdade por toda a vida do réu / condenado, tem o Estado o poder de fazer isso? O judiciário do Tribunal Europeu dos Direitos Humanos (em Estrasburgo / França) não pôde responder, consequentemente, à questão avassaladora: o caso Vinter e, posteriormente, o caso Hutchinson formaram pontos de vista polêmicos e comprometedores. A Hungria introduziu um remédio jurídico importante, devolvendo a esperança de ser libertado - mesmo condicionalmente: - após 40 anos de prisão, uma Comissão Nacional especialmente formada para esta finalidade, terá autoridade para revisar o 
ABOUT LIFELONG AND REAL LIFELONG SENTENCE (SEMI)PERMEABILITY OF THEORY AND PRACTICE SUPRANATIONAL JUDICIAL APPROACH BY THE EUROPEAN COURT OF HUMAN RIGHTS

comportamento da pessoa condenada na prisão, examinando se ele ou ela pode ser devolvida à sociedade normal ... Pesado trabalho à Comissão, pesadas pré-condições serão dadas a pessoa aprisionada. 0 presente ensaio tenta esclarecer por que tem sido tão difícil alcançar uma solução comprometida com os princípios e normas da Convenção. Aproveite e forme sua própria opinião.

Palavras-chave: Convenção Europeia de Direitos Humanos; Pena de Morte; Abolição.

\section{RESUMEN}

Desde la abolición total de la pena de muerte en los países que forman las Altas Partes Contratantes del Convenio Europeo de Derechos Humanos (47 Estados), se ha formado una situación molesta. Diferentes pros y contras han estado aumentando desde entonces. ¿Podría haber una sanción complementaria para los delitos más brutales, similares a la tortura y más crueles cometidos principalmente por seres humanos inocentes que privan su vida en formas agravadas? La respuesta es: 'sip' ... con muchas barreras, condiciones previas y requisitos previos. ¿Pensando profundamente en la privación de libertad durante toda la vida del acusado / convicto si el Estado está facultado para hacerlo? La propia judicatura del Tribunal Europeo de Derechos Humanos (en Estrasburgo / Francia) no pudo responder a la pregunta con entusiasmo: el caso Vinter y luego el caso Hutchinson han formado puntos de vista controvertidos que comprometen la aplicación. Hungría ha introducido un remedio legal muy especial que devuelve la esperanza de ser liberado, incluso de manera condicional: - después de pasar 40 años en prisión, una Comisión Nacional estrictamente constituida tiene derecho a revisar el comportamiento y la actitud de la persona condenada demostrada durante la prisión y presumiendo si él / ella ella podría ser devuelta a la sociedad normal ... ... deber pesado para la Comisión y una precondición pesada para la persona encarcelada. El ensayo intenta aclarar por qué ha sido tan difícil lograr una solución más o menos comprometida para cumplir con el espíritu y el texto escrito de la Convención. Disfruta y forma tu propia opinión.

Palabras clave: Comisión Europea de Derechos Humanos; Pena de muerte; Abolición.

\section{SUMMARY}

INTRODUCTION; 1 BRIEF HISTORY: TOWARD DENIAL OF SENTENCING TO DEATH PENALTY; 2 EUROPEAN CONVENTION ON HUMAN RIGHTS; 3 BASIC ELEMENTS OF THE CASE-LAW OF ECTHR; 3.1 Vinter and others V. UK (Applications nos. 66069/09, 130/10 and 3896/10); 3.2 The afterlife of the Vinter case great controversy supposed to be explained; REFERENCES.

\section{INTRODUCTION}

Since the total abolition of death penalty by the European Convention on Human Rights ${ }^{1}$ not only between utilitarists but amongst everydays' people has also been generated a continuous debate hence a serious populist need has also been eagerly arisen for a so called supplementary penalty which has defined the fate of most serious penalties for a very long period between the High Contracting Parties of the Council of Europe.

That might be also perceived that the question - as an aftermath of revival of death penalty in the US and ongoing issue in the P.R. of China and other significant Far-East countries has got some kind of ricochet during the past decade at least.

${ }^{1}$ Protocol No. 6. Art. 1 (done in Strasbourg. 28.04.1983). 


\section{BRIEF HISTORY: TOWARD DENIAL OF SENTENCING TO DEATH PENALTY}

Community of civilized nations has been split for a long period regarding adjudication whether sentencing criminals to death really refers to humanitarian considerations or not.

The question is always upsets smaller-bigger groups of different societies.

Hence the statement seems to be more or less justifiable for the first glance: none of States are granted to decide exclusive upon humanitarian considerations when applying or denying death penalty a contrario to the general will of the people.

Peoples' community - better to appoint: society - nevertheless is being also split by various viewpoints of different approaches depending on the individuals' entire social position, knowledge and attitude plus a lot of characterizing circumstances which might only been slightly circumscribed but never strictly defined. Probably some decades it would take for the completion by criminal-sociologists and interdisciplinarity experts.

Law is only one certain viewpoint but not the only one.

Whatever has led to the abolition of death penalty it has also stimulated lawmakers to hire another instrument within the legal frames of penalties as substantive law category in order to well-balance and fill the space having been born immediately.

The motion was definitely that death penalty had jumped out from the cage built for the well-known purpose: permanently isolating the actor of the serious criminal offence (felony) from the society by physical termination of his/her life.

Taking into consideration that terminating of the life of a human being might display the endless and all-above power of the State, humanitarian principles came across and halted the practice of executions. The elemental motivation was arising from the revelation of the undisputable fact: the state including all its legislative, enforcing and of other nature powers has always been above all, so strong that can afford even the deprivation of the individual life that is why it is not justifiable by some views.

Instead it became clear indeed that there are several very serious felonies committed by heavy criminals - as well as recidivists committing more aggravated criminal offences - which have even been shouting for a raw justice arisen from the people's general will.

Keeping in mind that the evolution of the human society has continuously moved toward classic democracies there are still deep concerns about the relation between the political structure and social architecture of a sovereign state and its nation and the tools have been elaborated by the organs of the direct/indirect democratic mechanisms. 
The most famous example is the temporary limitation and abolishment using death penalty in different states of the USA ${ }^{2}$ then a resurrection of the institution.

One might assume that the history of death penalty has gone through a kind of development of the relation between populism and the democratic and humanitarian considerations giving birth to a substantive category: there are serious felonies which deadly do 'cry' for the most serious punishment.

High Contracting Parties ${ }^{3}$ (hereinafter: HCP) of the Council of Europe (CoE) and the European Union ${ }^{4}$ (as forerunning toward the Fundamental Charter) are to be said flagships in elaborating principally and practically the most appropriate institutions of the comprehensive system for criminal punishments.

Since it became obvious for the past few decades that elemental principles are fundamentally characterizing a state's general behavior in the environment of the supranational legal architecture it is also undisputable that there are still heavy signs of refusing attitude against the attempts from the supranational legal entities.

While intrusions are being perceived by judicial supremacies through the judgments of international courts, decisions of former commissions and - as a highlighted phenomenon - the jurisprudence of subordinate national Courts and Constitutional Courts are also deeply involved in the improvement of judicial debates around penalty systems and tools.

\section{EUROPEAN CONVENTION ON HUMAN RIGHTS}

The first milestone on the way to abolishment of death penalty in Europe was the establishment of the European Convention on Human Rights ${ }^{5}$ (ECHR).

ECHR was drafted as an international treaty to protect human rights and fundamental freedoms in Europe almost just after WWII (1950: Statute of Rome).

ECHR's Article 2 protects the right of every person to life without any kind of discrimination:

ARTICLE 2

Right to life

\footnotetext{
${ }^{2}$ Furman vs. Georgia, Federal Supreme Court's Decision 1972.

$347 \mathrm{HCP}$.

${ }^{4} 28$ Memberstates (also HCP of the CoE, i. e. , "double Membership”).

5 COUNCIL OF EUROPE. European Convention on Human Rights. 1950. Available at: <https://www.echr.coe.int/Documents/Convention_ENG.pdf> Accessed on: 8 nov. 2018.
} 
ABOUT LIFELONG AND REAL LIFELONG SENTENCE -

(SEMI)PERMEABILITY OF THEORY AND PRACTICE SUPRANATIONAL JUDICIAL APPROACH BY THE EUROPEAN COURT OF HUMAN RIGHTS

KATONA TIBOR

1. Everyone's right to life shall be protected by law. No one shall be deprived of his life intentionally save in the execution of a sentence of a court following his conviction of a crime for which this penalty is provided by law.

2.Deprivation of life shall not be regarded as inflicted in contravention of this Article when it results from the use of force which is no more than absolutely necessary:

(a) in defence of any person from unlawful violence;

(b) in order to effect a lawful arrest or to prevent the escape of a person lawfully detained;

(c) in action lawfully taken for the purpose of quelling a riot or insurrection.

No one might have doubts that right to life covers the whole lifespan of a human being regardless its length and/or phase.

In the Evans v. UK Case ${ }^{6}$ it was clearly communicated however that the main issue of in vitro fertilisation (IVF) as a premiss of developing human embryos definitely arises a lot of sensitive issues around which also appear in the field of criminal justice as well.

Hungarian Fundamental Act (aka: Constitution) stipulates that beginning of life starts with fertilization. However the national Penal Code even on that ground threatens the murder of a born human by deprivation of liberty while killing an embryo still remained offence of less danger to society and more slightly punished.

Apart from that partial approach we are focusing on the real opportunities of depriving one's right to life physically as a punishment.

We had preliminary concerns that is it justifiable by the commonly spread narratives that ECHR does prohibit death penalty in general regardless whether there were justifiable grounds of applying that or not.

These concerns became absolutely unjustified.

Hence ECHR strictly stipulates - in Art.2. - that there might be situations when there is no conflict between the State's appliance of death penalty and the fundamental human right to life. Exclusions were introduced by the Protocol No.6.

However those strict stipulations involve serious conditions for turning to death penalty as an ultima ratio.

It is obvious for the time being that right to life forms only one side of the coin as a fundamentally justified phenomenon while the other side is a theoretical, non-existent in practice and most likely unjustifiable measure in the field of fighting even serious crime.

\footnotetext{
${ }^{6}$ EUROPEAN COURT OF HUMAN RIGHTS. Case of Evans v. The United Kingdom. Strasbourg, 10 apr. 2007. Available at: <https://hudoc.echr.coe.int/eng?i=001-80046\#\{\%22itemid\%22:[\%22001-80046\%22]\}>. Accessed on: 8 nov. 2018.
} 
Nowadays when several new international political issues put heavy burden on the shoulder of the community of civilized nations it is hard to decide whether a sovereign state is granted to use death penalty on the ground of its special viewpoints or not.

However for example Islamic State's jihad has ruined general confidence and faith planted into the peaceful minds worldwide that is why it is worth weighing that whether advantages are at stake when even speaking about death penalty or disadvantages too.

Extraordinary highlights might be perceived even all over the World (inc. South American negastates) that illegal immigration has been reveleaging for at least a three years period (from the autumn of 2015 in Central Europe) and at present the whole issue has grown a giant discimnination of a wide range of classic legal approaches like asylum as an undisputable human rights' category. We do mean that asylum is always supposed to be granted to all those who have been absolutely justified to be chased from their homeland, but the ecomigrants.

For a european Judge's mind that is undoubtedly unjustified to deprive one's life even in case of committing the most serious crimes providing peaceful times with regard to the exclusions having been made by the Convention and the Protocol.

Instead it is almost 'charming' to substitute that inhuman penalty with another one which is eligible to permanently isolate the defendant from the society. However this option is not short of heavy discussions and concerns too since European Court of Human Rights (hereinafter: ECtHR) has given strict and clear response to all those requests have been arisen by humanitarian considerations.

If we pin ECHR as a milestone for humanitarian considerations generally in Europe's historic map there must be at least two important cases undergoing a comprehensive legal analysis since from that point a group of HCP turned to a severe resistance to the ECtHR's supremacy.

\section{BASIC ELEMENTS OF THE CASE-LAW OF ECTHR}

\subsection{Vinter and others v. UK (Applications nos. 66069/09, 130/10 and 3896/10)}

Just for raising the attention it is more than worth highlighting that in that joint case the Grand Chamber has rendered final judgment ${ }^{7}$.

\footnotetext{
${ }^{7}$ Became final: 9 July 2013.
} 
The facts were briefly the following:

The applicants were three british citizens who committed serious felonies (solely).

Since the abolition of the death penalty in England and Wales, the sentence for murder has been a mandatory sentence of life imprisonment. Currently, when such a sentence is imposed, the trial judge is required to set a minimum term of imprisonment, which must be served for the purposes of punishment and retribution, taking into account the seriousness of the offence. The principles which guide the trial judge's assessment of the appropriate minimum term are set out in schedule 21 to the Criminal Justice Act 2003.

Once the minimum term has been served, the prisoner may apply to the Parole Board for release on licence.

Exceptionally, however, "a whole life order" may be imposed by the trial judge instead of a minimum term if, applying the principles set out in schedule 21 , he or she considers that the seriousness of the offence is exceptionally high.

The aftermath of such a serious penalty was that the person sentenced could not turn to any state organ for conditional release unless Secretary of State has ruled on the contrary.

However UK's Prison Service Rules would not allow conditional release simply on the ground of any other considerations as terminal illness or incapacitance of the detained.

This option has been granted for the detained only in cases when the trial judge did not impose a sentence on him/her keeping in mind that the criminal offence was so serious that there must not be any possibilities for conditional release.

The situation was obviously clear:

The trial judge is not able to adjudicate whether the detained for lifelong sentence might be eligible for conditional release in the near/far future or not. Moreover when Secretary of State had been given the opportunity to release the detained conditionally on the ground of the trial judge's positive opinion could also decide on the contrary: not releasing the detained at all which has obviously implied that Secretary of State became the "endpoint" for the person imprisoned. From entry into force of the 2003 Act it became possible to review these so called tariffs determined by the Secretary of State by the High Court.

The applicants turned to the ECtHR for remedy calling for determining UK's legal prescriptions and practice upon applying whole life sentence manifestly infringes the prohibition of inhuman, degrading treatment and punishment (ECHR Art.3.).

They argued via defending lawyers that the procedure when trial judge is entitled to decide upon a possible positive turn in one's attitude psychologically and not following the 
ABOUT LIFELONG AND REAL LIFELONG SENTENCE -

(SEMI)PERMEABILITY OF THEORY AND PRACTICE SUPRANATIONAL JUDICIAL APPROACH BY THE EUROPEAN COURT OF HUMAN RIGHTS

historical facts for the future, might form (and in their cases it became real) a prejudice that neither they nor anybody sentenced in the system shall be released conditionally even. They also claimed that such an entitlement was given to the High Courts and the Secretary of State as well similarly getting rid of a possible positive turn in the imprisoned general behavior.

As UK's State Agent highlighted during the procedure the relevant domestic case law has already given the principal and elemental compass for judges in such situations:

Such a sentence was partly punitive, partly preventative. The punitive element was represented by the tariff term, imposed as punishment for the serious crime which the convicted murderer had committed. The preventative element was represented by the power to continue to detain the convicted murderer in prison unless and until the Parole Board, an independent body, considered it safe to release him, and also by the power to recall to prison a convicted murderer who had been released if it was judged necessary to recall him for the protection of the public. ${ }^{8}$

Serious additional viewpoint was displayed also in another case where Lord Steyn has elaborated the rationae materiae for the whole life imprisonment case law:

...there is nothing logically inconsistent with the concept of a tariff by saying that there are cases where the crimes are so wicked that even if the prisoner is detained until he or she dies it will not exhaust the requirements of retribution and deterrence.

There was a sentence also referred which dealt inter alia with the Kafkaris Case before ECtHR as manifestation of a central doctrine"; concluded that "mandatory life sentence (...) is not normally irreducible sentence" ${ }^{\prime 10}$. In that case it was also pointed out that the practice of the Secretary of State was used "sparingly"11 - this wording is more than talkative. "Having observed that, in Kafkaris, this Court had found that the imposition of an irreducible life sentence might raise an issue under Article 3, the Court of Appeal went on to state".

More than worth underlining that this case was the first attempt of wording a light warning toward HCP: real lifelong sentence might form serious infringement and "attack" on Art. $3 .^{12}$

\footnotetext{
${ }^{8}$ In: R. v. Lichniak and R. v. Pyrah [2003] 1 AC 903, the House of Lords.

9 Case of KAFKARIS v. CYPRUS (Application no. 21906/04). Available at: <https://hudoc.echr.coe.int/eng\#\{\%22appno\%22:[\%2221906/04\%22]\}>. Accessed on: 8 nov. 2018.

${ }^{10}$ See: R v. Bieber [2009] 1 WLR 223.

11 See: R v. Bieber [2009] 1 WLR 223.

12 Another case for also famous for displaying such kind of calling for awareness: Törköly v. HUNGARY (Application no. 4413/06) with an alternative dismissal: the Court found the application inadmissible
} 
ABOUT LIFELONG AND REAL LIFELONG SENTENCE (SEMI)PERMEABILITY OF THEORY AND PRACTICE SUPRANATIONAL JUDICIAL APPROACH BY THE EUROPEAN COURT OF HUMAN RIGHTS

As a relation to the international cooperation in criminal matters there must be mentioned a case manifesting that the issue might rise serious concerns in those relations too:

The United States requested the extradition of Ralston Wellington from the United Kingdom to stand trial in Missouri on two counts of murder in the first degree. In his appeal against extradition, Mr. Wellington argued that his surrender would violate Article 3 of the Convention, on the basis that there was a real risk that he would be subjected to inhuman and degrading treatment in the form of a sentence of life imprisonment without parole. ${ }^{13}$

Such preliminary observations were complemented by the EEtHR with a widely completed analysis of the international and comparative criminal law practices and studies including the principal approach of the CoE's, the EU's and other relevant legal sources.

What could take the floor first than enumerating the crosspoints of the legal environment around the topic in Europe.

The ECtHR has stated that:

First, there are currently nine countries where life imprisonment does not exist: Andorra, Bosnia and Herzegovina, Croatia, Montenegro, Norway, Portugal, San Marino, Serbia and Spain. The maximum term of imprisonment in these countries ranges from twenty-one years in Norway to forty-five years in Bosnia and Herzegovina. In Croatia in a case of cumulative offences, a fifty-year sentence can be imposed.

Second, in the majority of countries where a sentence of life imprisonment may be imposed, there exists a dedicated mechanism for reviewing the sentence after the prisoner has served a certain minimum period fixed by law. Such a mechanism, integrated within the law and practice on sentencing, is foreseen in the law of thirty-two countries: Albania (25 years), Armenia (20), Austria (15), Azerbaijan (25), Belgium (15 with an extension to 19 or 23 years for recidivists), Bulgaria (20), Cyprus (12), Czech Republic (20), Denmark (12), Estonia (30), Finland (12), France (normally 18 but 30 years for certain murders), Georgia (25), Germany (15), Greece (20), Hungary (20 unless the court orders otherwise), Ireland (an initial review by the Parole Board after 7 years except for certain types of murders), Italy (26), Latvia (25), Liechtenstein (15), Luxembourg (15), Moldova (30), Monaco (15), Poland (25), Romania (20), Russia (25), Slovakia (25), Slovenia (25), Sweden (10), Switzerland (15 years reducible to 10 years), the former Yugoslav Republic of Macedonia (15), and Turkey (24 years, 30 for aggravated life imprisonment and 36 for aggregate sentences of aggravated life imprisonment).

Third, there are five countries which make no provision for parole for life prisoners: Iceland, Lithuania, Malta, the Netherlands and Ukraine. These countries do, however, allow life prisoners to apply for commutation of life sentences by means of ministerial, presidential or royal pardon. In Iceland,

however sent the 'message' to all National Courts. Available
<https://hudoc.echr.coe.int/eng\#\%7B\%22appno\%22:[\%224413/06\%22]\%7D>. Accessed on: 8 nov. 2018.
13 See: R (Wellington) v. Secretary of State for the Home Department [2008] UKHL 72.


ABOUT LIFELONG AND REAL LIFELONG SENTENCE -

(SEMI)PERMEABILITY OF THEORY AND PRACTICE SUPRANATIONAL JUDICIAL APPROACH BY THE EUROPEAN COURT OF HUMAN RIGHTS

although it is still available as a sentence, life imprisonment has never been imposed.

Fourth, in addition to England and Wales, there are six countries which have systems of parole but which nevertheless make special provision for certain offences or sentences in respect of which parole is not available. These countries are: Bulgaria, Hungary, France, Slovakia, Switzerland (for sex or violent offenders who are regarded as dangerous and untreatable: see the CPT report at paragraph 64 above) and Turkey.

ECtHR highlighted especially the German situation with the view to the matter:

Focusing on a war-criminal's case it was expressively announced that even Constitution did not exclude the option of whole life sentence on the general ground of severity of a criminal offence (e.g.: war crimes).

What was slightly alien-body-like approach by the High Forum as taking the method to look overseas as well. Canada, Hong Kong, Mauritius, Namibia, New Zealand, South Africa and the US were taken just a glance in order to complete (?) ECtHR's special examination. ${ }^{14}$

Much comprehensive and useful is the entire enumeration of European legal frameworks and environment concerning the topic.

As for the basic legal materials like United Nation's Standard Minimum Rules for the treatment of Prisoners, the International Covenant on Civil and Political Rights, the ECHR itself with addition by the Recommendations (2003)22 and (2003)23 which refer to rehabilitation and the constructive preparation of prisoners for release, the leading Council of Europe instrument is the 2006 European Prison Rules seemed to be more reliable for finding an exhausting examination.

As a result of the comprehensive analysis and examination as well as weighing all relevant viewpoints related ECtHR found that the central element of the case was proportionality.

It was generally announced that grossly disproportionate punishments always build the cathegory of ill-treatment contrary to Art.3. of ECHR.

The Grand Chamber found also that from the three types of lifelong sentence the most infringing seems to be the third one which doesn't allow parole and conditional release at all.

While representative of the UK Government was entirely rigid and firm in their status of legality to the whole life sentence there was not any other left behind than to weigh: whether

\footnotetext{
${ }^{14}$ Carefully looking at such a periphrasis and analitics of absolutely different laws seems obviously not able to form a well-founded starting point for the deep analysis since ECtHR had to be submitted its own Rules of Procedure in terms of substantive legal requirements too (by the author).
} 
such an excluded option (i.e. no parole on condition release) does infringe the Article in focus or not.

It was decided finally - by gross majority of the Judges - that rendering the sentence embodying the non-option of conditional release from whole life sentence by the Judge (or Jury) judging the case definitely infringes Art. 3 of the Convention.

The main argue was and still is with a view to following the jurisdiction of the ECtHR that there always must be a tough and certain mechanism to supervise the possibility of a relocation of the inmate to the society after a longer period spent imprisoned.

This option might have not been accurately specified by the Court however it was clearly communicated that taking into account the judicial practice of the International Criminal Court in the Hague (NL) has already firmly elaborated that period saying twenty-five years imprisonment must be served before such an examination.

Here and now we cannot deal with dissenting opinion of individual Judge however it is very hard to predict whether any posterior Judgments will not find ever such further circumstances which might alter the rationae materiae of the decision and convincement of the Judicial Supremacy.

Our understanding is that UK has not adopted the Judgment despite of its duty to having seriously taken into consideration of the infringement of the Convention but it is well-known that the Cameron administration has rejected any possibilities for the future to keeping in mind the sentence by principal considerations.

Since Hungary has also lost the case Magyar v. Hungary ${ }^{15}$ on the same topic (i.e. whole life sentence) it is highly interesting to emphasize that Hungarian legislator almost immediately amended the substantive law stipulation: - after serving at least forty years imprisonment the detained has the fundamental right to pass an ex officio special examination by the Council of Mercy which must consist of high ranking Judges of the Curia as guaranteeing factor (in line with the remaining individual plea for mercy of course).

Each and every points of examination and procedural rules are being laid down in the Act in order to getting the balance between the prescriptions and stipulations of the ECHR and the justified need for extra isolation of the most serious criminals from the healthy body of the society.

15 EUROPEAN COURT OF HUMAN RIGHTS. Case of László Magyar v. Hungary. Strasbourg, 20 may 2014. Available at: <https://hudoc.echr.coe.int/eng?i=001-144109\#\{\%22itemid\%22:[\%22001-144109\%22]\}>. Accessed on: 8 nov. 2018. 
As time passed there had not been driven any of that special examination due to the fact that the new regulation already entried into force on 1th of November this year and there are no inmates has been serving 40 years imprisoned ever since.

There are already signs of non-satisfaction of some HR NGOs in the question: it is still not communicated officially but there might already been a certain application to the EctHR concerning the new Hungarian regulation.

In addition on the 1 th of July this year a Law Integrity Decision was rendered by the CURIA.

The definitive doctrine had been announced: real lifelong deprivation of liberty is an organic part of Hungarian Law and Order which shall not undergo the interpretation of the ECHR by the EctHR and its case law as well as previous decisions of the Constitutional Court even the CURIA's own recent concrete decision rendered in that frame.

That is all about the permeability: the Hungarian legislator on the initiative of the Ministry of Justice has given a more or less appropriate response to the supremative request which is reflected in the Law Integrity Decision's Ordering Part only with referral to it but real lifelong sentence is still standing. We guess the fixing mechanism will fulfill the requirements otherwise a total reform must be driven through the system.

\subsection{The afterlife of the Vinter case - great controversy supposed to be explained}

One could assume that the Vinter Judgment of the Grand Chamber became the real cornerstone and will not be revised ever.

That is the mistake of mistakes:

In the Hutchinson-case the same supranational court on the basis of the same UK legal facts/grounds have deliberated that "after all" UK has done and fulfilled all criteria concerned with the supervisory scope of the secretary of state, the judgment was release just after UK's actual PM declared that the Vinter-judgment has arisen tidal wave-like effect on HM the Queens sovereign jurisdiction that it is more than affectable to consider GB/UK's withdrawal from the ECHR and the scope of the ECtHR.

The question became of a general moral concern: Great Britain was amongst the cofounders of the Council of Europe and its legal environment.

Who's life is at stake anyway - we guess... 
ABOUT LIFELONG AND REAL LIFELONG SENTENCE -

(SEMI)PERMEABILITY OF THEORY AND PRACTICE SUPRANATIONAL JUDICIAL APPROACH BY THE EUROPEAN COURT OF HUMAN RIGHTS

\section{REFERENCES}

COUNCIL OF EUROPE. European Convention on Human Rights. 1950. Available at: <https://www.echr.coe.int/Documents/Convention_ENG.pdf> Accessed on: 8 nov. 2018.

EUROPEAN COURT OF HUMAN RIGHTS. Case of Evans v. The United Kingdom. Strasbourg, 10 apr. 2007. Available at: <https://hudoc.echr.coe.int/eng?i=001-80046\#\{\%22itemid\%22:[\%2200180046\%22]\}>. Accessed on: 8 nov. 2018.

EUROPEAN COURT OF HUMAN RIGHTS. Case of László Magyar v. Hungary. Strasbourg, 20 may 2014. Available at: <https://hudoc.echr.coe.int/eng?i=001-144109\#\{\%22itemid\%22:[\%22001144109\%22]\}>. Accessed on: 8 nov. 2018.

LICHNIAK, R.; PYRAH, R. 1 AC 903, the House of Lords. 2003.

\section{COMO FAZER A REFERÊNCIA DO ARTIGO (ABNT):}

TIBOR, Katona. About lifelong and real lifelong sentence - (semi)permeability of theory and practice - supranational judicial approach by the European Court of Human Rights. Revista Eletrônica do Curso de Direito da UFSM, Santa Maria, RS, v. 13, n. 3, p. 1232-1244, dez. 2018. ISSN 1981-3694. Disponível em: <

https: //periodicos.ufsm.br/revistadireito/article/view/35838 >. Acesso em: dia mês. ano. doi: http://dx.doi.org/10.5902/1981369435838. 